\title{
Contribution to the knowledge of fungal diversity of the Marmore Waterfalls (Umbria, central Italy)
}

\author{
Roberto Venanzoni', Enrico Bini', Emma Bricchi', Paola Angelini' \\ I Department of Chemistry, Biology and Biotechnology, University of Perugia, via del Giochetto - 06123, \\ Perugia, Italy \\ Corresponding author: Paola Angelini (paola.angelini@unipg.it)
}

Academic editor: L. Peruzzi | Received 24 January 2019 | Accepted 9 March 2019 | Published 26 March 2019

Citation: Venanzoni R, Bini E, Bricchi E, Angelini P (2019) Contribution to the knowledge of fungal diversity of the Marmore Waterfalls (Umbria, central Italy). Italian Botanist 7: 17-29. https://doi.org/10.3897/italianbotanist.7.33308

\begin{abstract}
A list of the macrofungi collected from the Marmore Waterfalls (Umbria, Italy) is reported. In particular, a list of basidiomycetes and ascomycetes collected over a period of about ten years was compiled. A total of 125 species belonging to 78 genera, 46 families, and 15 orders were identified. Forty-four species are recorded in Umbria for the first time. Marmore Waterfalls may represent an important area for the conservation of fungal diversity, due to the presence of 34 species matching those included in Red Lists of several European countries.
\end{abstract}

\section{Keywords}

Ascomycota, Basidiomycota, ecological-trophic group, EU Habitat $7220^{*}$

\section{Introduction}

The Marmore Waterfalls (Terni, Umbria) are man-made waterfalls originally built by the Romans in $271 \mathrm{BC}$ to divert the Velino River. Presently it is open to the public only when hydroelectric power is not being generated. With a total height of $165 \mathrm{~m}$ (541 feet), it is one of the highest man-made waterfalls in Italy and worldwide.

Due to the great biological richness in species and priority EU-Habitats, concentrated in about $0,86 \mathrm{~km}^{2}$, it is included within the protected natural area of the 'Nera River Regional Park'. It is also recognized at the European level as a Special Area of Conservation and Special Protection Area (SAC/SPA IT5220017) of the Natura 2000 EU-wide network (Habitat Directive 92/43/EEC). 
Among the habitats, the priority EU-Habitat 7220* [Petrifying springs with tufa formation (Cratoneurion)] is one of the most important for its naturalistic features. Petrifying springs are lime-rich water sources which deposit tufa or travertine. The emerging spring water is rich in carbon dioxide and dissolved calcium carbonate. On contact with the atmosphere, carbon dioxide is outgassed and calcium carbonate is deposited as tufa. Communities associated with petrifying springs, namely fungi, plants and animals are highly specialized due to their challenging environment (high $\mathrm{pH}$, constant inundation by water and deposition of precipitated calcium carbonate) (Aleffi and Spampinato 2009, Lyons and Kelly 2016). At sites such as waterfalls (e.g., Marmore Waterfalls) and springs, carbonate deposition is frequently extremely local (Ford and Pedley 1996).

The specific microclimate of the Marmore Waterfalls, showing high levels of ionized water aerosols, gives rise to the presence of a significant mycological diversity, which makes the uniqueness of this Site of Community Importance even more evident. A research project has been underway in this area for about ten years, leading to the census of well over 100 species of epigeal fungi.

Fungi constitute one of the largest and most significant groups of organisms in the world. They are valuable not only for their vital roles in ecosystem functions, but also for their influence on humans and human-related activities (Zervakis and Venturella 2007, Saitta et al. 2011, Pecoraro et al. 2014, Angelini et al. 2015a, 2016a, 2016b). They are responsible for a range of key ecological functions, including nutrient cycling, water uptake by plants and soil health and formation (Picco et al. 2011, Perotto et al. 2013, Frąc et al. 2018).

With regard to human-related activities, mushrooms are also involved and/or exploited in forestry, pharmaceutical industry and food production. Hence, they represent a major economic resource worldwide (Angelini et al. 2008, 2015b, 2018, Pagiotti et al. 2011, Bonanno et al. 2019). In order to maintain and to improve their strategic importance, several conservation strategies are needed (Wagensommer et al. 2018).

In this paper, a checklist of fungi occurring at the Marmore Waterfalls is reported with the aim of contributing to the knowledge about the biodiversity in this area.

\section{Material and methods}

\section{Study area}

The Marmore Waterfalls $\left(42^{\circ} 33^{\prime} 15.56^{\prime \prime} \mathrm{N}, 12^{\circ} 42^{\prime} 44^{\prime \prime} \mathrm{E}\right)$, extending over an area of about $1,59 \mathrm{~km}^{2}(200-360 \mathrm{~m}$ a.s.1.), is located in the province of Terni, the southeastern part of Umbria (Fig. 1).

The rock wall that gives rise to the waterfall is divided into three interspersed drops. When the waterfall is closed, ponds carved into the rock by the power of water can be seen.

The study area was located on the left side of the Nera River, specifically on a series of Pleistocene terraces characterized by fluvial-lacustrine and travertine deposits (Car- 
rara et al. 1993), ending at the base of the waterfall where the Velino River flows into the Nera River. The study area continues along the pathways that rise to the upper overlook. The lithology is characterized by crossings, whose deposition of calcareus travertine (or tufa) is still active, and in which there are interesting cavities. According to IT5220017 Natura 2000-Standard Data Form (http://www.regione.umbria. it/ambiente/siti-di-importanza-comunitaria-sic/), the EU-habitats investigated were: 91E0*, alluvial forests with Alnus glutinosa and Fraxinus excelsior (Alno-Padion, Alnion incanae, Salicion albae; 92A0, Salix alba and Populus alba galleries; 6430, hydrophilous tall herb fringe communities of the plains and the mountains to alpine levels; $7220^{*}$, petrifying springs with tufa formation (Cratoneurion); 9340, Quercus ilex and Quercus rotundifolia forests. They are mostly located at the base of rock faces, and subject to water spray on organic debris colonised by briophytes (Ellis et al. 2014, Poponessi et al. 2014, Ellis et al. 2016, 2017, 2018).

\section{Macrofungal species sampling}

Mycological sampling was carried out starting in 2008. Sampling was performed monthly, in particular, along the areas adjacent to the waterfall (EU-Habitat $7220^{*}$ ), along the different paths that go through the Park (Fig. 1).

Collections were made by samplings of each ascoma and basidioma. The surveys were limited to macromycetes that were visible to the naked eye $(1 \mathrm{~mm}$ in size) (sensu Arnolds 1981).

The macromycetes were identified based on macro and micromorphological features according to the descriptions available in literature (Dennis 1978, Moser 1980, Jülich 1989, Candusso and Lanzoni 1990, Courtecuisse and Duhem 1994, Basso 1999, Hrouda 1999, Bernicchia 2005, Bernicchia and Gorjón 2010, Breitenbach and Kränzlin 1984, 1986, 1991, 1995, 2000, Franchi and Marchetti 2001, Robich 2003). For species names and author abbreviations, the Index Fungorum (http:// www.indexfungorum.org/Names/Names.asp) and Dictionary of the Fungi (Kirk et al. 2008) were used.

The voucher specimens were dried in air-ventilated ovens at $30^{\circ} \mathrm{C}$ for $72 \mathrm{~h}$ and deposited at the PeruMyc herbarium of the Department of Chemistry, Biology and Biotechnology of the University of Perugia (Italy).

\section{Ecological and statistical analyses}

Species richness was calculated as the number of taxa collected over the ten years. Macrofungal diversity was determined using Fisher's alpha $(\mathrm{F})$, Shannon $(\mathrm{H})$ and Simpson (1/D) indices (Fisher et al. 1943). Similarity of the macrofungal communities among the five EU-habitat was examined with similarity indices based on presence/absence data (Jaccard's index). 


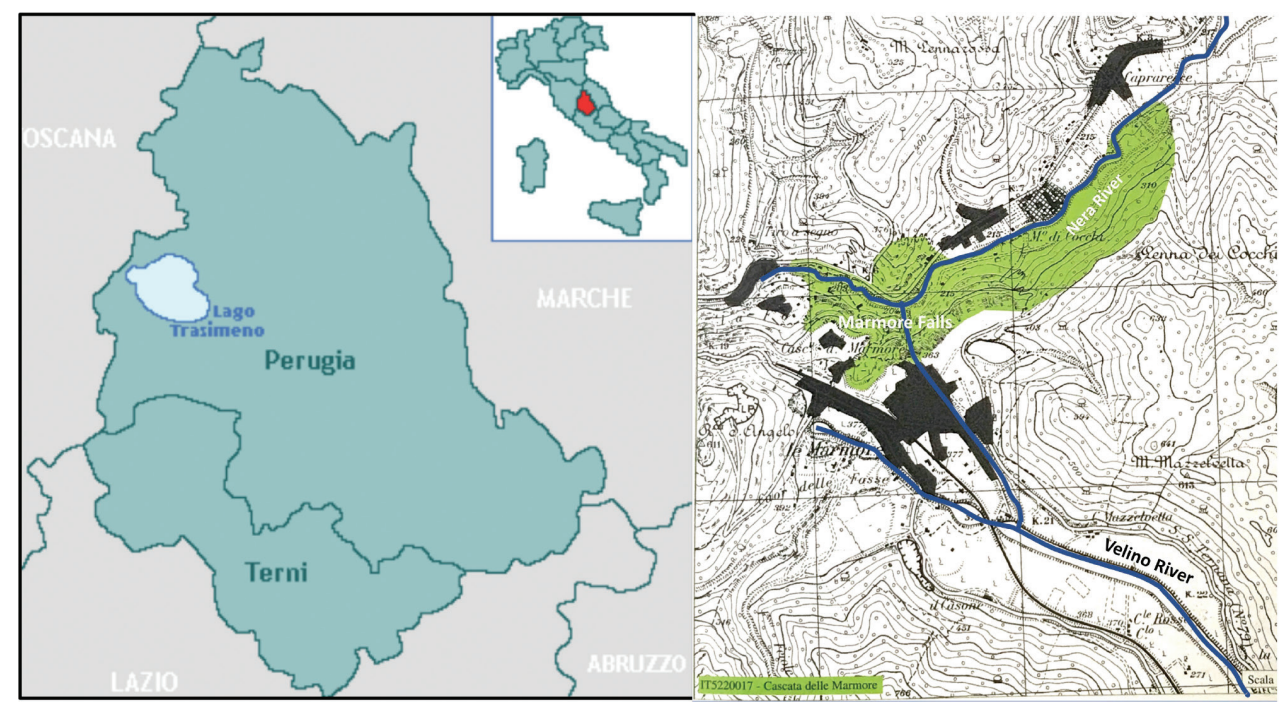

Figure I. (draft) Marmore Waterfall Site of Community Importance according to Habitats Directive (92/43/EEC) IT IT5220017: the study area in green.

These parameters were calculated using ESTIMATES 9.1.0 (R.K. Colwell, http://purl.oclc.org/estimates). The macrofungal species were also classified into ecological trophic groups based on their primary mode of nutrition (Arnolds et al. 1995; Tedersoo and Smith 2013; Tedersoo et al. 2014).

\section{Results}

The Marmore Waterfalls, repeatedly surveyed from 2008-2018, showed the presence of 125 species belonging to 78 genera, 46 families, and 15 orders (Suppl. material 1: Table S1, Figs 2-3). Sixty-nine families belong to the Basidiomycota class and 7 to the Ascomycota.

The largest number of orders (12), genera (70) and species (107) belongs to Basidiomycota. Eighteen species, included in 8 genera, 7 families, and 3 orders belong to Ascomycota (Suppl. material 1: Table S1, Figs 2, 3). The Fisher's $\alpha$, Shannon J' and Simpson (1/D) diversity indices, based on species number per genus, were 88.73, 4.18, and 52.26, respectively.

Agaricales was the most represented order, hosting the largest number of genera, followed by Polyporales and Boletales (Fig. 3). The families that had the highest number of species were Agaricaceae (10), Psathyrellaceae (9), Physalacriaceae, and Helvellaceae (7), Inocybaceae (6), and Tricholomataceae (6), which collectively accounted for approximately $30 \%$ of diversity (Suppl. material 1: Table S1). Helvella was the most diverse genus with 7 species, followed by Coprinopsis (6), Mycena (5), Inocybe (4), and Peziza (4) (Suppl. material 1: Table S1). 


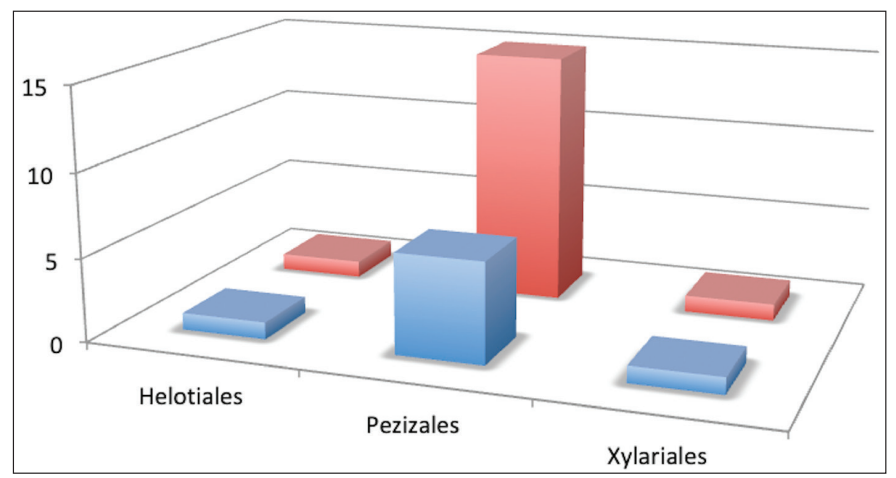

Figure 2. Distribution of macrofungal species and genera per order of Ascomycota: (i) blue columns indicate the number of genera; (ii) red columns indicate the number of species.

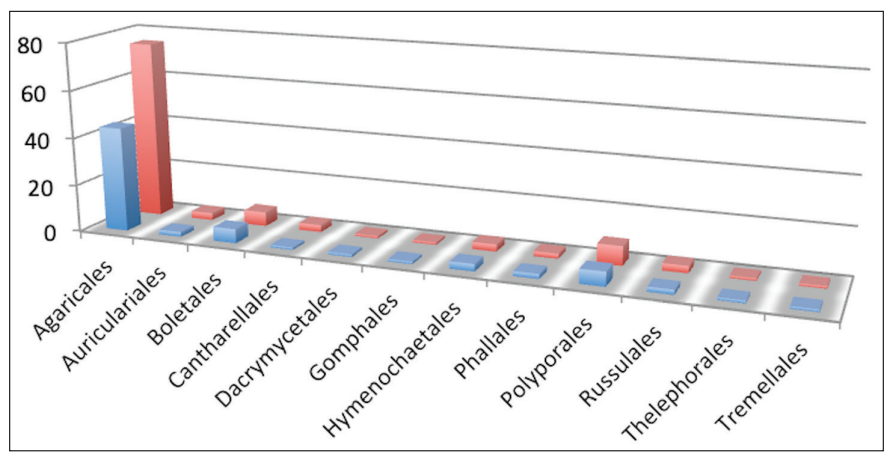

Figure 3. Distribution of macrofungal species and genera per order of Basidiomycota: (i) blue columns indicate the number of genera; (ii) red columns indicate the number of species.

The list of the species with their ecological trophic group is reported in Suppl. material 1: Table $S 1$.

The two main trophic groups were the saprotrophs and ectomycorrhizals, with a total number of 97 and 22 species, respectively.

The saprotrophs were mainly either terrestrial (St) or lignicolous $(\mathrm{Sh})$, which account for $33.6 \%$ and $29.6 \%$, respectively.

The other groups $[\mathrm{Pn}, \mathrm{Pn}(\mathrm{Sh})]$ collectively represented only $4.8 \%$ of the total diversity (Suppl. material 1: Table S1, Fig. 4).

With reference to the Umbrian Checklist of macrofungi (Angelini et al. 2017), 44 species new for the region were found at the Marmore Waterfalls. Thirty-four species included in Red Lists of European countries (http://www.wsl.ch/eccf/) were also found at the site. These species are indicated with the symbols* and ^, respectively, in Suppl. material 1: Table $S 1$.

Fungal community composition varied across the EU-habitat types, as shown in Suppl. material 1: Table S1. Most of the species were sparsely distributed, occurring 


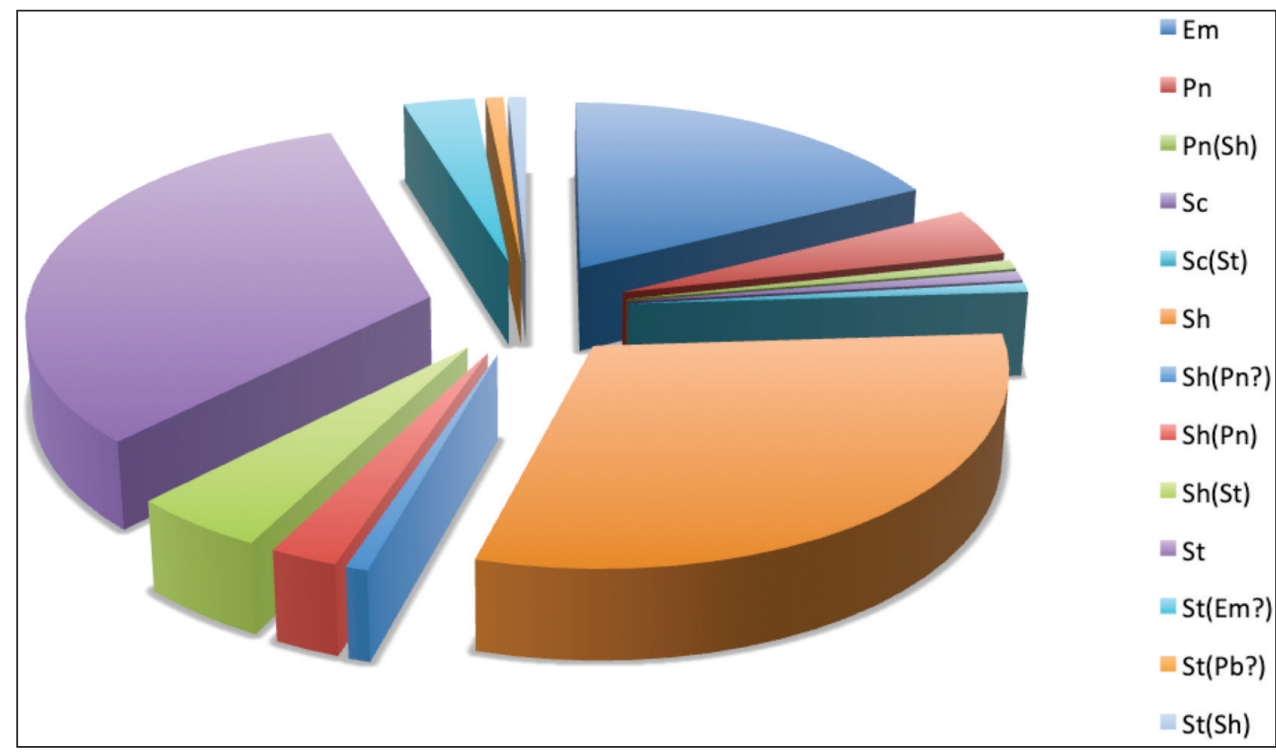

Figure 4. Distribution of macrofungal species per ecological-trophic group (Em, ectomycorrhizal; Pn, necrotrophic parasite; $\mathrm{Pn}(\mathrm{Sh})$, necrotrophic parasite or sometimes lignicolous saprotroph; Sc, coprophilous; $\mathrm{Sc}(\mathrm{St})$, coprophilous or maybe terrestrial saprotroph; Sh, lignicolous saprotroph; $\mathrm{Sh}(\mathrm{Pn})$, lignicolous saprotroph or sometimes necrotrophic parasite; $\mathrm{Sh}(\mathrm{Pn}$ ?), lignicolous saprotroph or maybe necrotrophic parasite; $\mathrm{Sh}(\mathrm{St})$, lignicolous saprotroph or sometimes terrestrial saprotroph; $\mathrm{St}$, terrestrial saprotroph; $\mathrm{St}(\mathrm{Em}$ ?), terrestrial saprotroph or maybe ectomycorrhizal; $\mathrm{St}(\mathrm{Pb}$ ?); terrestrial saprotroph or maybe biotrophic parasite).

in few habitat types. More specifically, 108 species were found in only one habitat, 15 were in two types, and 3 in three types.

Regarding the main trophic groups, St species ranged from $22.95 \%$ in habitat 9340 to $58.33 \%$ in habitat $7220^{*}$; Sh species were absent in habitat 6430 and ranged from $22.95 \%$ in habitat 9340 to $39 \%$ in habitat $92 \mathrm{~A} 0$. Em species in habitat 9340 $(34.42 \%)$ were more abundant than saprophic species (Sh or St). Contrarily, in habitats 91E0* and 92A0, Em species were less abundant than Sh/St species. In habitats 6430 and $7220^{*}$, Em species were absent (Suppl. material 1: Table S2).

The similarity among EU-habitat types calculated on the basis of presence-absence of fungal species (Jaccard's index) ranged from 0.095 (EU-habitat 9340 vs. EU-habitat 92A0) to 0 (EU-habitat 9340 vs. EU-habitat 7220*) (Suppl. material 1: Table S3). EU-habitats 6340 and $7220^{*}$ had the most distinctive macrofungal community. Bolbitius titubans, Lacrymaria lacrymabunda and Agrocybe vervacti were restricted to 6340 (Suppl. material 1: Table S1). Some Ascomycota, such as Helvella corium, H. crispa, Peziza domiciliana, P. queletii, Scutellinia scutellata, and Tarzetta cupularis seem to be important biotic components of the priority EU-Habitat $7220^{*}$ together with some Basidiomycota, such as Echinoderma calcicola, Mycena galopus, Phloeomana conopilea, P. hiemalis, P. speirea, and Psathyrella candolleana (Suppl. material 1: Table S1, Figs S1, S2). 


\section{Discussion}

This study provided a list of 125 macrofungal species identified at the Marmore Waterfalls over the last ten years (2008-2018) in different Natura 2000 EU-Habitats. Macrofungal communities are structured by host plants/EU-habitats. Similarity was very low among EU-Habitat types, with the exception of 9340 and 92A0 which shared 9 fungal species (Agaricus moelleri, Auricularia mesenterica, Calocera cornea, Clathrus ruber, Schizophyllum commune, Lepista nuda, L. sordida, Tubaria furfuracea, T. romagnesiana).

The dominant tree species of habitats 9340 and $92 \mathrm{A0}$ differed; thus, 9340 showed higher mycorrhizal species richness, while $92 \mathrm{~A} 0$ had a higher relative number of saprotrophic macrofungi.

Despite the fact that this study is an initial qualitative survey of the macrofungi (based on the presence-absence of species) from the Marmore Waterfalls, it provided a list of 12 fungal species for Habitat 7220*, "Petrifying spring with tufa formation (Cratoneurion)", reported here for the first time and never before documented in previous studies in Italy. In general, they are alkalotolerant species (ecological-trophic group: St, terrestrial saprotrophic) and represent, along with the bacteria, the major taxa responsible for decomposing and recycling various organic materials produced by primary producers, the resilient remains of other organisms (bryophytes, algae, protozoans, metazoans, etc.) and dissolved organic compounds (Madigan et al. 2003).

Among the small number of ascomycetes collected during this study, there are five species reported by Wagensommer et al. (2018) as endangered (Morchella esculenta, Scutellinia scutellata) or "vulnerable" (Helvella leucomelaena, Peziza succosa, Saecoscypha coccinea) in Umbria, because of the threat to their status due to natural or anthropic action.

Of the 34 fungal species included in Red Lists of European countries (http:// www.wsl.ch/eccf/) is noteworthy the presence of: (1) Coprinopsis strossmayeri, a rare species in Italy (Suppl. material 1: Fig. S3), previously collected only in Piemonte (Vizzini 2001); (2) Echinoderma calcicola, a widespread but rare European species, reported only in five other Italian regions (Lombardia, Marche, Piemonte, Toscana, and Veneto) (Onofri et al. 2005). It is considered as "endangered" in the Sweden Red List (Tingstad et al. 2017).

While further study based on fruiting body abundance is needed to provide a measure of the relative importance of a species in EU-habitats, it can be concluded that this ten-year survey has demonstrated that the diversity of the fungi at the Marmore Waterfalls is remarkable, given the high number of species identified in a very small area. The data collected also contribute to draft a naturalistic plan of the Marmore Waterfalls, and provide useful information for monitoring habitats and species of European interest (as required by the Important Plant Areas program and Habitat Directive 92/43/EEC). Important Plant Areas (IPAs) are the most important places in the world for wild plant and fungal diversity, that can be protected and managed as specific sites (Blasi et al. 2009, 2011). The IPA project forms an integral part of a much wider conservation framework, from the global Convention on Biological Diversity framework to regional pan-European and European Union initiatives (Planta Europa 
2008, Darbyshir et al. 2017). It gives the possibility of becoming part of conservation actions to countries, habitats and organisms, in some way not considered in the Habitat Directive 92/43/CEE (Perini et al. 2011). Its aim is to identify priority sites using three criteria (threatened species, exceptional botanical richness, and threatened habitats) and to work towards their conservation and management (Anderson 2002, Venturella et al. 2011).

\section{References}

Aleffi M, Spampinato G (2009) Habitat 7220. In: Biondi E, Blasi C, Burrascano S, Casavecchia S, Copiz R, Del Vico E, Galdenzi D, Gigante D, Lasen C, Spampinato G, Venanzoni R, Zivkovic L (Eds) Manuale Italiano di interpretazione degli habitat della Direttiva 92/43/CEE. SBI, MATTM, DPN.

Anderson S (2002) Identifying Important Plant Areas. Plantlife, 50 pp.

Angelini P, Arcangeli A, Bistocchi G, Rubini A, Venanzoni R, Perini C (2017) Current knowledge of Umbrian macrofungi (central Italy). Plant Biosystems 151(5): 915-923. https:// doi.org/10.1080/11263504.2016.12656

Angelini P, Bistocchi G, Arcangeli A, Bricchi E, Venanzoni R (2015a) Diversity and ecological distribution of macrofungi in a Site of Community Importance of Umbria (Central Italy). The Open Environmental Research Journal 8: 1-8. https://doi. org/10.2174/1874213001508010001

Angelini P, Bistocchi G, Arcangeli A, Rubini A, Venanzoni R (2016a) Inventory, diversity and communities of macrofungi in the Collestrada forest (Umbria, Central Italy). Plant Biosystems 150(5): 1096-1105. https://doi.org/10.1080/11263504.2015.1108939

Angelini P, Compagno R, Arcangeli A, Bistocchi G, Gargano ML, Venanzoni R, Venturella G (2016b) Macrofungal diversity and ecology in two Mediterranean forest types. Plant Biosystems 150: 540-549. https://doi.org/10.1080/11263504.2014.987844

Angelini P, Granetti B, Pagiotti R (2008) Effect of antimicrobial activity of Melaleuca alternifolia essential oil on antagonistic potential of Pleurotus species against Trichoderma harzianum in dual culture. World Journal of Microbiology and Biotechnology 24: 197-202. https://doi.org/10.1007/s11274-007-9456-x

Angelini P, Tirillini B, Bistocchi G, Arcangeli A, Rubini A, Pellegino RM, Fabiani R, Cruciani G, Venanzoni R, Rosignoli P (2018) Overview of the biological activities of a methanol extract from wild Red Belt Conk, Fomitopsis pinicola (Agaricomycetes), fruiting bodies from central Italy. International Journal of Medicinal Mushrooms 20(11): 1047-1063. https:// doi.org/10.1615/IntJMedMushrooms.2018028595

Angelini P, Tirillini B, Properzi A, Rol C, Venanzoni R (2015b) Identification and bioactivity of the growth inhibitors in Tuber spp. methanolic extracts. Plant Biosystems 149(6): 1000-1009. https://doi.org/10.1080/11263504.2014.983575

Arnolds E (1981) Ecology and coenology of macrofungi in grasslands and moist heathlands in Drenthe, the Netherlands. Part 1. Introduction and Synecology. Biblioteca Mycologica 83: $1-410$. 
Arnolds E, Kuyper TW, Noordeloos EM (1995) Overview of the fungi in the Netherlands. Wijster, Nederlandse Mycologische Vereniging, 872 pp.

Basso MT (1999) Lactarius Pers. Fungi Europaei. Alassio, 845 pp.

Bernicchia A (2005) Polyporaceae s.l., Fungi Europaei, 10. Alassio, 808 pp.

Bernicchia A, Gorjön SP (2010) Corticiaceae s.l. Fungi Europaei, 12. Alassio, 1008 pp.

Blasi C, Marignani M, Copiz R, Fipaldini M (2009) Mapping the Important Plant Areas in Italy. Palombi Editori, Roma.

Blasi C, Marignani M, Fipaldini M, Copiz R (2011) Between global priorities and local urgencies: the Important Plant Areas programme in Italy. Fitosociologia 48(2) suppl. 1: 137-143.

Bonanno A, Di Grigoli A, Vitale F, Di Miceli G, Todaro M, Alabiso M, Gargano ML, Venturella G, Anike FN, Isikhuemhen OS (2019) Effects of diets supplemented with medicinal mushroom myceliated grains on some production, health, and oxidation traits of dairy Ewes. International Journal of Medicinal Mushrooms 21(1): 69-103. https://doi. org/10.1615/IntJMedMushrooms.2018029327

Breitenbach J, Kränzlin F (1984) Champignons de Suisse, 1. Les Ascomycetes. Lucerne.

Breitenbach J, Kränzlin F (1986) Champignons de Suisse, 2. Champignons sans lames. Hétérobasidiomycétes, Aphyllophorales, Gastéromycétes. Lucerne.

Breitenbach J, Kränzlin F (1991) Champignons de Suisse, 3. Bolets et champignons a’ lames. lére partie. Strobilomycetaceae, Boletaceae, Paxillaceae, Gomphidiaceae, Hygrophoraceae, Tricholomataceae, Polyporaceae (lamellées). Lucerne.

Breitenbach J, Kränzlin F (1995) Champignons de Suisse, 4. Bolets et champignons á lames. 2eme partie. Entolomataceae, Pluteaceae, Amanitaceae, Agaricaceae, Coprinaceae, Bolbitiaceae, Strophariaceae. Lucerne.

Breitenbach J, Kränzlin F (2000) Champignons de Suisse, 5. Champignons á lames. 3eme partie. Cortinariaceae. Lucerne.

Candusso M, Lanzoni G (1990) Lepiota s.l. Fungi Europaei 4. G. Biella Editions, Saronno, Italy, $743 \mathrm{pp}$.

Carrara C, Brunamonte F, Ferrell L, Lorenzoni P, Margheriti L, Michetti AM, Raglione M, Rosati M, Serva L (1993) I terrazzi della medio-bassa valle del F. Velino. Studi Geologici Camerti 1992(1): 97-102, 5ff., Camerino.

Courtecuisse R, Duhem B (1994) Les champignons de France. Paris.

Darbyshire I, Anderson S, Asatryan A, Byfield A, Cheek M, Clubbe C, Ghrabi Z, Harris T, Heatubun CH, Kalema J, Magassouba S, McCarthy B, Milliken W, de Montmollin B, Lughadha EN, Onana JM, Saïdou D, Sârbu A, Shrestha K, Radford EA (2017) Important Plant Areas: revised selection criteria for a global approach to plant conservation. Biodiversity Conservation 26: 1767-1800. https://doi.org/10.1007/s10531-017-1336-6

Dennis RWG (1978) British Ascomycetes. Vaduz.

Ellis LT, Afonina OM, Aleffi M, Andriamiarisoa RL, Bačkor M, Goga M, Bednarek-Ochyra H, Callaghan DA, Campisi P, Dia MG, Marino ML, Enroth J, Erzberger P, Hugonnot V, Ignatova EA, Kiebacher T, Kučera J, Lebouvier M, Maria GM, Ştefănuţ S, Nagy J, Pócs T, Poponessi S, Venanzoni R, Gigante D, Prosser F, Reeb C, Sabovljević MS, Shevock JR, Shirzadian S, Akhoondi Darzikolaei S, Souza ERF, Silva Pinto A, Silva JB, Lopes SF, Torzewski K, Kazienko A (2018) New national and regional bryophyte 
records, 55. Journal of Bryology 40(2): 173-187. https://doi.org/10.1080/03736687. 2018.1454161

Ellis LT, Alataş M, Aleffi M, Alegro A, Šegota V, Ozimec S, Vuković N, Koletić N, Prlić D, Bontek M, Asthana AK, Gupta D, Sahu V, Rawat KK, Bakalin VA, Klimova KG, Baráth K, Beldiman LN, Csiky J, Deme J, Kovács D, Cano MJ, Guerra J, Czernyadjeva IV, Dulin MV, Erzberger P, Ezer T, Fedosov VE, Fontinha S, Sim-Sim M, Garcia CA, Martins A, Granzow-de la Cerda I, Sáez L, Hassel K, Weibull H, Hodgetts NG, Infante M, Heras P, Kiebacher T, Kučera J, Lebouvier M, Ochyra R, Ören M, Papp B, Park SJ, Sun BY, Plášek V, Poponessi S, Venanzoni R, Purger D, Reis F, Sinigla M, Stebel A, Ştefãnuţ S, Uyar G, Vončina G, Wigginton MJ, Yong KT, Chan MS, Yoon YJ (2017) New national and regional bryophyte records, 52. Journal of Bryology 39(3): 285-304. https://doi.org/10.10 80/03736687.2017.1341752

Ellis LT, Aleffi M, Alegro A, Segota V, Asthana AK, Gupta R, Singh VJ, Bakalin VA, BednarekOchyra H, Cykowska-Marzencka B, Benitez A, Borovichev EA, Vilnet AA, Konstantinova NA, Buck WR, Cacciatoro C, Sérgio C, Csiky J, Deme J, Kovács D, Damsholt K, Enroth J, Erzberger P, Fedosov VE, Fuertes E, Gradstein SR, Gremmen NJM, Hallingbäck T, Jukonienė I, Kiebacher T, Larraín J, Lebouvier M, Lüth M, Mamontov YS, Potemkin AD, Nemeth C, Nieuwkoop JAW, Nobis M, Węgrzyn M, Wietrzyk P, Osorio F, Parnikoza I, Virchenko VM, Peralta DF, Carmo DM, Plášek V, Skoupá Z, Poponessi S, Venanzoni R, Puche F, Purger D, Reeb C, Rios R, Rodriguez-Quiel E, Arrocha C, Sabovljević MS, Nikolić N, Sabovljević AD, dos Santos EL, Segarra-Moragues JG, Ştefănuţ S, Stončius D (2016) New national and regional bryophyte records, 48. Journal of Bryology 38(3): 223-244. https://doi.org/10.1080/03736687.2016.1206685

Ellis LT, Aleffi M, Asthana AK, Srivastava A, Bakalin VA, Batan N, Özdemir T, BednarekOchyra H, Borovichev EA, Brugués M, Cano MJ, Choi SS, De Beer D, Eckstein J, Erzberger P, Fedosov VE, Ganeva A, Natcheva R, Garcia CA, Sérgio C, Garilleti R, Albertos B, Puche F, Gücel S, Higuchi M, Hugonnot V, Hylander K, Kirmaci M, Aslan G, Koponen T, Lara F, Mazimpaka V, van Melick H, Müller F, Özenoglu Kiremit H, Papp B, Szurdoki E, Plášek V, Čihal L, van der Pluijm A, Poponessi S, Mariotti MG, Reyniers J, Sabovljević MS, Sawicki J, Smith VR, Stebel A, Ştefănuţ S, Sun BY, Váňa J, Venanzoni R (2014) New national and regional bryophyte records, 40. Journal of Bryology 39(3): 235-259. https:// doi.org/10.1179/1743282014Y.0000000115

Fisher RA, Corbet AS, Williams CB (1943) The relation between the number of species and the number of individuals in a random sample of an animal population. Journal of Animal Ecology 12: 42-58. https://doi.org/10.2307/1411

Ford TD, Pedley HM (1996) A review of tufa and travertine deposits of the world. EarthScience Reviews 41: 117-175. http://doi.org/10.1016/S0012-8252(96)00030-X

Frąc M, Hannula SE, Bełka M, Jędryczka M (2018) Fungal biodiversity and their role in soil health. Frontiers in Microbiology 9: 107. http://doi.org/10.3389/fmicb.2018.00707

Franchi P, Marchetti M (2001) Introduzione allo studio del genere Ramaria in Europa. Fungi non Delineati 16: 1-104.

Hrouda P (1999) Hydnaceous fungi of the Czech Republic and Slovakia. Czech Mycology 51(2-3): 99-155. 
Jülich W (1989) Guida alla determinazione dei funghi, 2. Aphyllophorales, Heterobasidiomycetes, Gasteromycetes. Saturnia Ed. Trento, 598 pp.

Kirk PM, Cannon PF, Stalpers JA (2008) Dictionary of the Fungi. $10^{\text {th }}$ ed. Wallingford: CAB International. $784 \mathrm{pp}$.

Lyons MD, Kelly DL (2016) Monitoring guidelines for the assessment of petrifying springs in Ireland. Irish Wildlife Manuals, No. 94. National Parks and Wildlife Service, Department of Arts, Heritage, Regional, Rural and Gaeltacht Affairs, Ireland.

Madigan MT, Martinko JM, Parker JPH (2003) Brock Biology of Microorganisms. $10^{\text {th }}$ ed, Upper Saddle River, NJ Prentice Hall London Pearson Education.

Moser MM (1980) Guida alla determinazione dei funghi. (Polyporales, Boletales, Agaricales, Russulales). Saturnia, Trento, 565 pp.

Onofri S, Bernicchia A, Filipello Marchisio V, Padovan F, Perini C, Ripa C, Savino E, Venturella G, Vizzini A, Zotti M, Zucconi L (2005) Checklist of Italian fungi. Carlo Delfino Editions, Sassari.

Pagiotti R, Angelini P, Rubini A, Tirillini B, Granetti B, Venanzoni R (2011) Identification and characterisation of human pathogenic filamentous fungi and susceptibility to Thymus schimperi essential oil. Mycoses 54: e364-376. https://doi.org/10.1111/j.14390507.2010.01926.x

Pecoraro L, Angelini P, Arcangeli A, Bistocchi G, Gargano ML, La Rosa A, Lunghini D, Polemis E, Rubini A, Saitta S, Venanzoni R, Zervakis GI (2014) Macrofungi in mediterranean maquis along seashore and altitudinal transects. Plant Biosystems 148(2): 367-376. https://doi.org/10.1080/11263504.2013.877535

Perini C, Leonardi P, Pecoraro L, Salerni E (2011) The Important Plant Areas program from a mycological point of view: the regional experience in an European context. Fitosociologia 48(2) suppl. 1: 155-161.

Perotto S, Angelini P, Bianciotto V, Bonfante P, Girlanda M, Kull T, Mello A, Pecoraro L, Perini C, Persiani AM, Saitta A, Sarrocco S, Vannacci G, Venanzoni R, Venturella G, Selosse A (2013) Interaction of fungi with other organisms. Plant Biosystems 147: 208-218. https:// doi.org/10.1080/11263504.2012.753136

Picco AM, Angelini P, Ciccarone C, Franceschini A, Ragazzi A, Rodolfi M, Varese GC, Zotti M (2011) Biodiversity of emerging pathogenic and invasive fungi in plants, animals and humans in Italy. Plant Biosystems 145: 988-996. https://doi.org/10.1080/11263504.2011.633118

Planta Europa (2008) A Sustainable future for Europe; the European strategy for plant conservation 2008-2014. Plant life International and the Council of Europe, 57 pp.

Poponessi S, Aleffi M, Venanzoni R (2014) Conocephalum salebrosum Szweykowski, Buczkowska et Odrzykoski (Conocephalaceae, Marchantiophyta), new to Italy. Cryptogamie, Bryologie 35(2): 223-226. https://doi.org/10.7872/cryb.v35.iss2.2014.223

Robich G (2003) Mycena d'Europa. A.M.B. Fondazione, Centro Studi. Micologici, Vicenza, $728 \mathrm{pp}$.

Saitta A, Bernicchia A, Gorjon SP, Altobelli E, Granito VM, Losi C, Lunghini D, Maggi O, Medardi G, Padovan F, Pecoraro L, Vizzini A, Persiani AM (2011) Biodiversity of wooddecay fungi in Italy. Plant Biosystems 145(4): 958-968. https://doi.org/10.1080/112635 04.2011 .633114 
Tedersoo L, Smith ME (2013) Lineages of ectomycorrhizal fungi revisited: foraging strategies and novel lineages revealed by sequences from belowground. Fungal Biology Reviews 27: 83-99. https://doi.org/10.1016/j.fbr.2013.09.001

Tedersoo L, Bahram M, Pólme S, Kóljalg U, Yorou NS, Wijesundera R, Ruiz LV, Vasco-Palacios AM, Thu PQ, Suija A, Smith ME, Sharp C, Saluveer E, Saitta A, Rosas M, Riit T, Ratkowsky D, Pritsch K, Póldmaa K, Piepenbring M, Phosri C, Peterson M, Parts K, Pärtel K, Otsing E, Nouhra E, Njouonkou AL, Nilsson RH, Morgado LN, Mayor J, May TW, Majuakim L, Lodge DJ, Lee SS, Larsson KH, Kohout P, Hosaka K, Hiiesalu I, Henkel TW, Harend H, Guo L, Greslebin A, Grelet G, Geml J, Gates G, Dunstan W, Dunk C, Drenkhan R, Dearnaley J, Kesel AD, Dang T, Chen X, Buegger F, Brearley FQ, Bonito G, Anslan S, Abell S, Abarenkov K (2014) Global diversity and geography of soil fungi. Science 346(6213): 1256688. https://doi.org/10.1126/science.1256688

Tingstad L, Gjerde I, Dahlberg A, Grytnes JA (2017) The influence of spatial scales on Red List composition: forest species in Fennoscandia. Global Ecology and Conservation 11: 247-297. https://doi.org/10.1016/j.gecco.2017.07.005

Venturella G, Altobelli E, Bernicchia A, Di Piazza S, Donnini D, Gargano ML, Gorjòn SP, Granito VM, Lantieri A, Lunghini D, Montemartini A, Padovan F, Pavarino M, Pecoraro L, Perini C, Rana G, Ripa C, Salerni E, Savino E, Tomei PE, Vizzini A, Zambonelli A, Zotti M (2011) Fungal biodiversity and in situ conservation in Italy. Plant Biosystems 145: 950-957. https://doi.org/10.1080/11263504.2011.633115

Vizzini A (2001) A rare species in the Valentino Park (Turin): Coprinopsis strossmayeri. Bollettino del Gruppo Micologico G. Bresadola, n.s. 44(1): 4-12.

Wagensommer RP, Bistocchi G, Arcangeli A, Rubini A, Perini C, Venanzoni R, Angelini P (2018) An assessment of red list data for the Pezizomycotina (Ascomycota): Umbria (Italy) as a test case. Plant Biosystems 152(6): 1329-1337. https://doi.org/10.1080/11263504.2 018.1448015

Zervakis GI, Venturella G (2007) Adverse effects of human activities on the diversity of macrofungi in forest ecosystems. Bocconea 21: 77-84. 


\section{Supplementary material I}

\section{Supplementary tables and figures}

Authors: Roberto Venanzoni, Enrico Bini, Emma Bricchi, Paola Angelini

Data type: species data

Explanation note: Table S1. List of macrofungal species collected in the Marmore Waterfalls, Terni, Umbria. Table S2. Percentage of relative abundance and number (in parentheses) of fungal species from each ecological group in the Marmore Waterfalls EU- habitats [91E0*, Alluvial forests with Alnus glutinosa and Fraxinus excelsior (Alno Padion, Alnion incanae, Salicion albae); 92A0, Salix alba and Populus alba galleries; 6430, Hydrophilous tall herb fringe communities of the plains and the mountains to alpine levels; 7220*, Petrifying springs with tufa formation (Cratoneurion); 9340, Quercus ilex and Quercus rotundifolia forests]. Table S3. Similarity of macrofungi communities with respect to EU-habitat [91E0*, Alluvial forests with Alnus glutinosa and Fraxinus excelsior (Alno-Padion, Alnion incanae, Salicion albae); 92A0, Salix alba and Populus alba galleries; 6430, Hydrophilous tall herb fringe communities of the plains and of the mountains to alpine levels; $7220^{*}$, Petrifying springs with tufa formation (Cratoneurion); 9340, Quercus ilex and Quercus rotundifolia forests], reflecting similarity based on presence/absence data only (Jaccard's index). Figure S1. Ascomycota species found in EU Habitat 7220* (Marmore Waterfalls, TR): 1) Helvella corium (O. Weberb.) Massee, 2) H. crispa (Scop.) Fr., 3) Peziza domiciliana Lantieri \& Cacialli, 4) Peziza queletii Medardi, 5) Scutellinia scutellata (L.) Lambotte and 6) Tarzetta cupularis (L.) Svrček. Figure S2. Basidiomycota species found in EU Habitat 7220* (Marmore Waterfalls, Terni, Umbria): 1) Echinoderma calcicola (Knudsen) Bon, 2) Mycena galopus (Pers.) P. Kumm, 3) Parasola conopilus (Fr.) Örstadius \& E. Larss, 4) Phloeomana hiemalis (Osbeck) Redhead, 5) P. speirea (Fr.) Redhead and 6) Psathyrella candolleana (Fr.) Maire. Figure S3. Coprinopsis strossmayeri (Schulzer) Redhead, Vilgalys \& Moncalvo: 1) basidiocarps. Microscopic features (1000x): 2) hyphae with a joint buckle, 3) details of the veil, 4) spores.

Copyright notice: This dataset is made available under the Open Database License (http://opendatacommons.org/licenses/odbl/1.0/). The Open Database License $(\mathrm{ODbL})$ is a license agreement intended to allow users to freely share, modify, and use this Dataset while maintaining this same freedom for others, provided that the original source and author(s) are credited.

Link: https://doi.org/10.3897/italianbotanist.7.33308.suppl1 